\title{
Hydrogeological Characterization and Groundwater Resources Assessment of the Chtouka Coastal Aquifer (SOUTH-WEST, Morocco)
}

\author{
Soukaina Benkou ${ }^{\text {, }}$ Abdelkader Larabi ${ }^{1}$, Mohamed Faouzi $^{1}$, Oussama Ait Raoui ${ }^{2}$ \\ ${ }^{1}$ Laboratory of Analysis and Modeling of the Environment and Natural Resources "AMERN ", Mohammadia Scholl of Engineers , \\ Mohammed V University, Rabat, Morocco . \\ ${ }^{2}$ Hydraulic Basin Agency of Souss Massa, Morocco
}

Résumé : L'aquifère côtier de Chtouka, d'une superficie de $1250 \mathrm{~km}^{2}$, se situe au Sud de la ville d'Agadir, dans le bassin du Massa. L'aquifère de Chtouka est constitué par un complexe de formations hétérogènes représentées principalement par les alluvions et les calcaires lacustres Plio-quaternaires qui reposent sur les marnes et les marnes sableuses du Miocène. Ces dernières constituent le substratum de l'aquifère Plio-quaternaire. Les eaux souterraines de la nappe de Chtouka sont destinées principalement à l'usage agricole et pour l'alimentation en eau potable des centres de Biougra et Ait-Amira et des communes rurales de la plaine. Les prélèvements moyens des eaux de la nappe sont estimés à $85 \mathrm{Mm} 3$ /an, durant la période 2000-2015, et dont $90 \%$ correspondent aux prélèvements par pompages agricoles. Ces prélèvements ont engendré un déstockage de $58 \mathrm{Mm} 3$ /an des réserves en eau de la nappe. Cette dernière est alimentée principalement par l'infiltration des eaux de pluies et en partie par la percolation des excédents des eaux d'irrigation de surface dont le mode gravitaire ne couvre que $2 \%$ du périmètre d'irrigation d'une superficie de 17260 ha. L'analyse des chroniques piézométriques, réalisée pour la série d'années 1968-2020, a mis en évidence une baisse généralisée du niveau de la nappe avec des valeurs de rabattement comprises entre 3 et $35 \mathrm{~m}$. Les secteurs les plus affectés par la baisse se situent dans la moitié septentrionale où les valeurs atteignent $35 \mathrm{~m}$ au nord-ouest, $9 \mathrm{~m}$ au nord autour de Biougra-Ait Amira et de l'ordre de $14 \mathrm{~m}$ au sud. Plus à l'Est, les valeurs des rabattements cumulés enregistrés oscillent autour de $8 \mathrm{~m}$. Ces rabattements sont plus faibles dans la zone côtière à l'ouest et ne dépassent guère $3 \mathrm{~m}$. La baisse manifeste dans les secteurs nord de la nappe se rapporte à la réduction de la recharge de la nappe suite aux successions des années sèches mais principalement à l'exploitation intensive de la nappe par les pompages agricoles. Au nordouest, la baisse du niveau piézométrique de la nappe est modérée par la mise en eau du périmètre irrigué moderne de la grande hydraulique de Massa desservi à partir des eaux du barrage Youssef Ben Tachefine. En vue d'améliorer nos connaissances sur le fonctionnement de la nappe, nous avons réalisé une étude hydrogéologique de la nappe en vue d'identifier et évaluer ces ressources en eau, en termes de piézométrie actualisée et de nouveau bilan, qui ont été très impactés par les dernières sècheresses successives qui ont frappées la région depuis 2014. Cette évaluation actualisée de ces ressources en eau souterraines va aussi contribuer à une gestion meilleure de la nappe de Chtouka et assister le gestionnaire à la prise de bonne décision quant la planification des ressources en eau.

Mots-clés : Aquifère côtier de Chtouka ; Eaux souterraines ; Hydrogéologie, Piézométrie, Rabattement, bilan.

\begin{abstract}
The coastal aquifer of Chtouka, with an area of $1250 \mathrm{~km}^{2}$, is located south of Agadir city in the Massa basin. The Chtouka aquifer is made up of a complex of heterogeneous formations mainly represented by alluvium and Plio-Quaternary lacustrine limestones which rest on the marls and sandy marls of the Miocene, which constitutes the substratum of this aquifer. The groundwater of the Chtouka aquifer is mainly used for agricultural and drinking water supply of Biougra, Ait Amira centers, and the rural communes of the plain. The average water withdrawals from the groundwater during the period of 2000-2015 are estimated at $85 \mathrm{Mm}^{3} /$ year, of which $90 \%$ corresponds to withdrawals by agricultural pumping. These withdrawals generated $58 \mathrm{Mm}^{3} /$ year which has led to a depletion of the groundwater reserves. The aquifer reservoir is mainly supplied by the infiltration of rainwater and partly by the irrigation water percolation by gravity which covers only $2 \%$ of the irrigation perimeter with a surface area of 17260 ha. The analysis of piezometric records, carried out for the series of years 1968-2020, showed a general decrease of groundwater level with drawdown values between 3 and $35 \mathrm{~m}$. The sectors most affected by this decrease are located in the northern half where values reach $35 \mathrm{~m}$ in the northwest, $9 \mathrm{~m}$ in the north around Biougra - Ait Amira, and around $14 \mathrm{~m}$ in the south. Further east, the recorded cumulative drawdown values oscillate around $8 \mathrm{~m}$. These drawdowns are lower in the coastal zone to the west and hardly exceed $3 \mathrm{~m}$. The obvious drop in the northern sectors of the study area is due to the reduction in groundwater recharge following the succession of dry years, but mainly due to the intensive exploitation of groundwater by agricultural pumping. In the northwest, the drop in the piezometric level is moderated by the impoundment of the modern irrigated perimeter of the Massa large hydraulics, served from the Youssef Ben Tachefine dam water reservoir. To improve our knowledge and our relevant understanding of this aquifer's functioning, a hydrogeological study was carried out to identify and assess these water resources, in terms of updated piezometric and new balance. Indeed, the aquifer was greatly impacted by the last successive droughts which have hit the region since 2014. This updated assessment of these groundwater resources will contribute to better management of the Chtouka aquifer and will assist the manager in making the right decision regarding water resources planning.
\end{abstract}




\section{Introduction :}

The chtouka water table is among the most important water tables in the Souss Massa region. It contributes to the drinking water supply of the town of Biougra and Ait Amira and the neighboring centers as well as the irrigation of agricultural land.

The Chtouka plain is the main greengrocer area in Morocco; it concentrates $30 \%$ of the area of early vegetables in Morocco and represents nearly $50 \%$ of total national production and provides the bulk of national exports of early vegetables. [1]

The objectives of this study are to characterize the chtouka water table, develop a database and carry out a hydrogeological study of the water table, evaluation of groundwater resources.

\section{Material and methods:}

\subsection{Situation of the Study Area:}

The coastal aquifer of Chtouka is located south of the city of Agadir, in the Massa basin. It is limited:

* West by the Atlantic Ocean, a western outlet for groundwater

* East by feed limit with the Anti Atlas ;

* To the south by the boundary with the Wadi Massa, constituting a water drainage line ;

* To the north by the hydraulic limit with the Sous water table. (Figure 1)

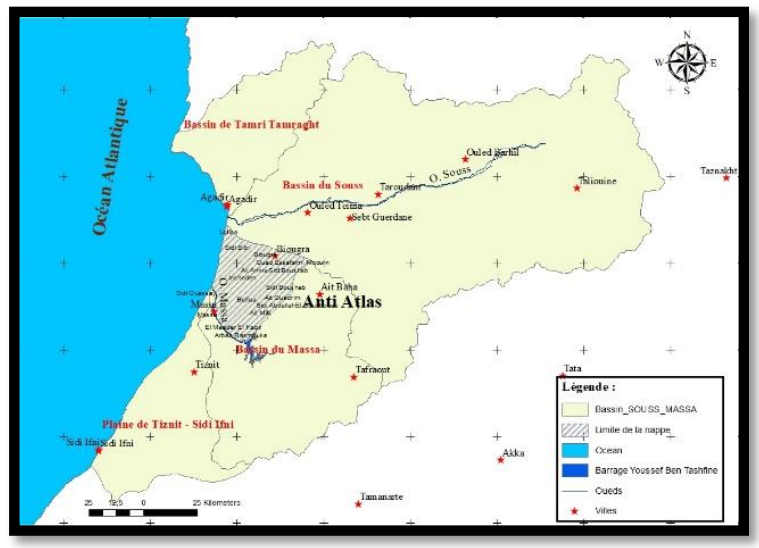

Figure 1: Location of the study area

\subsection{Hydrology}

The Massa watershed is broken down into 6 sub-basins with a total area of approximately $6,100 \mathrm{~km}^{2}$. It is drained by the Wadi Massa and its tributaries: the wadis of Amaghouz and Assaka, which both originate in the Atlantic part of the Anti-Atlas, which constitute the Major hydrographic element in the region of Massa. (Figure 2, Table 1)
The Principal wadi that drains the chtouka slick is Wadi Massa

\begin{tabular}{|c|c|c|c|c|c|c|}
\hline & $\begin{array}{l}\text { Sub- } \\
\text { basin } \\
\text { name }\end{array}$ & $\begin{array}{c}\text { Area } \\
\left(\mathrm{Km} \mathrm{m}^{2}\right. \\
)^{2}\end{array}$ & $\begin{array}{l}\text { Peri } \\
\text { met } \\
\text { er ( } \\
{ }^{\circ} \mathrm{K} \\
\mathrm{m})\end{array}$ & $\begin{array}{c}\text { Gra } \\
\text { veli } \\
\text { u } \\
\text { inde } \\
\text { x }\end{array}$ & $\begin{array}{c}\text { Equiv } \\
\text { alent } \\
\text { lengt } \\
\text { h }\end{array}$ & $\begin{array}{c}\text { Equival } \\
\text { ent } \\
\text { width } \\
\text { (km) }\end{array}$ \\
\hline \multirow{3}{*}{$\begin{array}{c}\text { BV } \\
\text { O. } \\
\text { Mas } \\
\text { sa }\end{array}$} & Sfa & $\begin{array}{c}321 \\
.49\end{array}$ & 176.2 & 2.75 & 84.29 & 7.3 \\
\hline & $\begin{array}{c}\text { Taka } \\
\mathrm{t}\end{array}$ & $\begin{array}{r}471 \\
.52\end{array}$ & $\begin{array}{c}126.3 \\
5\end{array}$ & 1.63 & 54.53 & 14.93 \\
\hline & $\begin{array}{c}\text { El } \\
\text { Maa } \\
\text { dar } \\
\text { Lakb } \\
\text { ir }\end{array}$ & $\begin{array}{r}149 \\
.37\end{array}$ & 72.14 & 1.65 & 31.3 & 8.28 \\
\hline \multirow{3}{*}{$\begin{array}{c}\text { Mas } \\
\text { sa } \\
\text { Rest } \\
\text { ant }\end{array}$} & $\begin{array}{c}\text { Ama } \\
\text { ghou } \\
\text { z }\end{array}$ & $\begin{array}{c}142 \\
1.6 \\
5\end{array}$ & $\begin{array}{c}178.6 \\
5\end{array}$ & 1.33 & 68.6 & 31.83 \\
\hline & $\begin{array}{c}\text { Mass } \\
\text { a }\end{array}$ & $\begin{array}{c}262 \\
1.0 \\
6\end{array}$ & $\begin{array}{c}226.2 \\
5\end{array}$ & 1.24 & 80.61 & 46.34 \\
\hline & $\begin{array}{c}\text { Taze } \\
\text { roual } \\
\mathrm{t}\end{array}$ & $\begin{array}{c}113 \\
0.4 \\
3\end{array}$ & $\begin{array}{c}225.3 \\
6\end{array}$ & 1.88 & $\begin{array}{c}1010 \\
55\end{array}$ & 20.06 \\
\hline
\end{tabular}

\section{Tableau 1:Characteristics of the Massa sub-basins [2]}

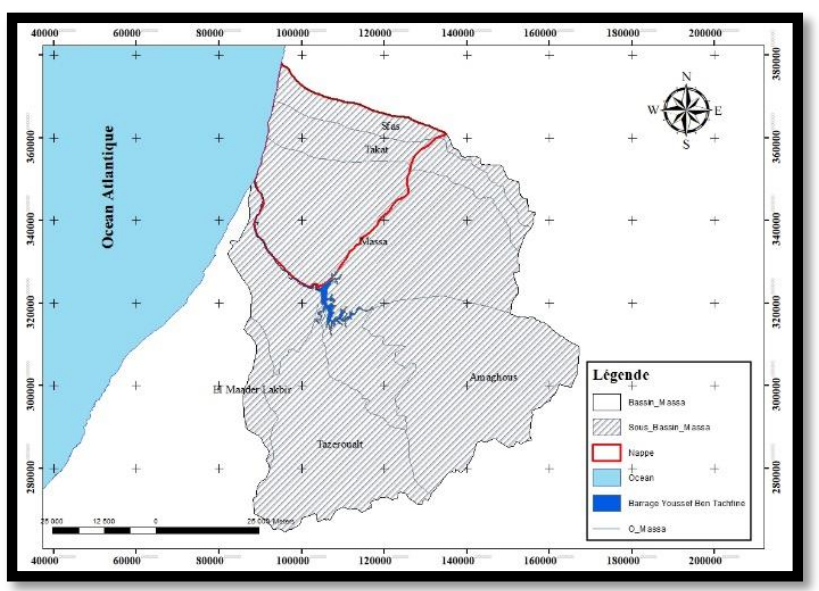

Figure 2: Location of sub-basins

\subsection{Use of groundwater}

Groundwater from the water table is used for agricultural use and to supply drinking water

\subsubsection{Agricultural use}

The Chtouka water table constitutes the main water resource for agricultural use and for supplying drinking water to the centers of Biougra , Ait Amira ,and the rural communes of the plain. 
The chtouka region is endowed with significant hydro-agricultural equipment and three irrigated perimeters:

The Modern public perimeter of Massa with an area of 18,050 ha which is located about forty kilometers south of the city of Agadir. This perimeter was filled with water between July 1974 and December 1975. It benefits from a surface water allocation from the Youssef Ben Tachafine dam of $75 \mathrm{Mm}^{3}$. Most of the total area (97\%) is Melk land. The remaining 3\% is collective land.[1]

The Tassila and Oughzifen perimeters with an area of 1200 ha. They benefit from a surface water allocation of $10 \mathrm{Mm}^{3}$ from the Youssef Ben Tachafine dam. [1]

The private perimeter of Chtouka covers an average area of 10,000 ha, mainly to the north of the public perimeter, and to the west in the buffer zone of the Massa Natural Park. The private sector, mainly in the North (Sidi Bibi, Ait Amira, Biougra) is characterized by the importance of market gardening (> 70\%), in particular greenhouse market gardening. [1]

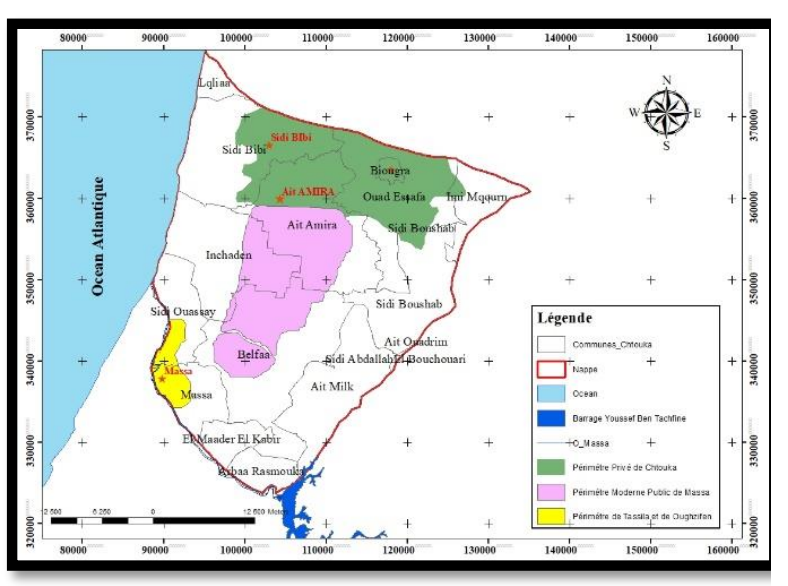

Figure 3 : Situation of the irrigation schemes of the Chtouka plain

\subsubsection{Drinking water supply}

The municipalities and centers of the Chtouka plain are supplied by wells and boreholes. The volume taken in 2011 is $2.5 \mathrm{Mm}^{3}$. With the same rate of change observed, this volume would be $3 \mathrm{Mm}$.

\subsection{Geology}

The main aquifer is made up of dune sandstones with sandy pasts and levels of lacustrine limestone intercalated from the Upper Quaternary and Villafranchien. In the northern part of Chtouka, the following facies can be distinguished: [3]
* The Late Quaternary consists of dunes about 10-12 km wide along the coastline, and up to more than $100 \mathrm{~m}$ thick [3]

* The middle and lower Quaternary (Villafranchien) is made up of dune and limestone sandstones 20 to $100 \mathrm{~m}$ thick, containing in intercalation a level of lake limestone that can be more or less marly from 2 to $25 \mathrm{~m}$ thick. At the base, we find conglomerate or lacustrine deposits and sandstone formations. [3]

* The Pliocene and Miocene are represented by a formation of fluvio-lacustrine origin, made up of marly-sands, marls, and limestones. Their thickness varies from 50 to more than $500 \mathrm{~m}$. In the Biougra region, this formation passes laterally towards the east to gravel and gravel with marly-sandy cement, which decreases its permeability. [3]

* The Eocene is made up of limestones and sand-clay marls.

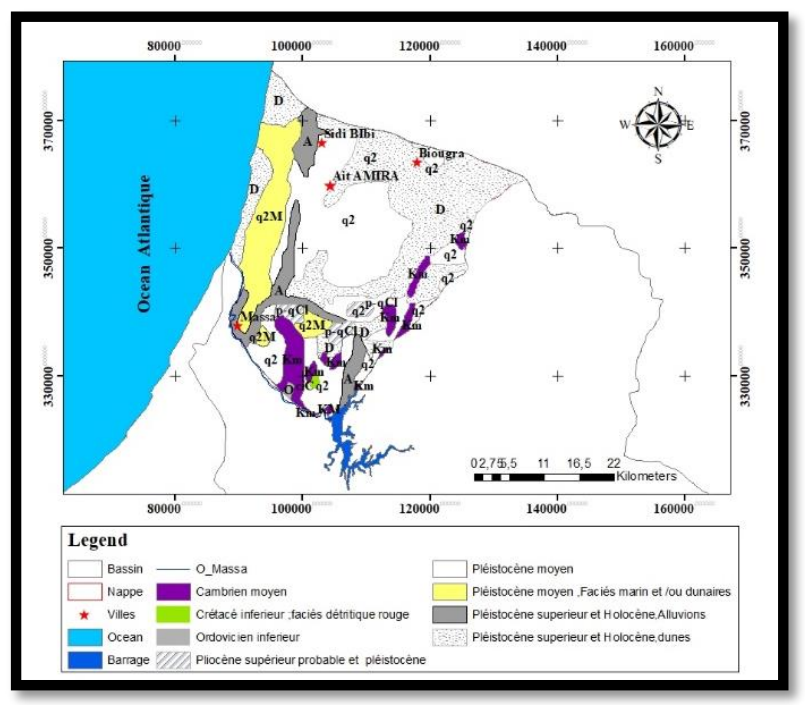

Figure 4: Geological map of the chtouka water table (Extract from the geological map of Morocco $1 / 100000)$

\subsection{Hydrodynamics of the chtouka study area}

The hydrodynamic characteristics (permeability, transmissivity $(\mathrm{T})$, and storage coefficient) are known thanks on the one hand to pumping tests provided by the Regional Directorate of Hydraulics (DRH) of the SOUSS and on the other hand, to the results of the calibration of the hydrodynamic model of the Souss aquifer.

The main results are:

\subsubsection{Transmissivity}


At the watershed level, the transmissivity values vary from 10-3 to 5.10-2 $\mathrm{m}^{2} / \mathrm{s}$, and the highest values are located around Biougra. This would be linked to the formation of Plio-Quaternary deposits by poorly rolled gravel and gravel (Hydraulic Basin Agency of Souss Massa, 2006); the lowest values are in the foothills of the Anti-Atlas.

The great variability of transmissivity reflecting the heterogeneity of the aquifer

\subsubsection{Permeability}

The permeability values which are calculated from the transmissivity values and the water slices or strainer heights are generally between 5.10-6 and 2.10-3 m / s. The most permeable areas are located along the Souss valley around Inezgane, then up to Ouled Teïma. The areas of low permeability are located in the foothills of the Anti-Atlas.[1]

\subsubsection{Piezometric}

Analysis of the available piezometric data (maps and piezometers) shows that the water table for 40 years has suffered a chronic deficit over the entire plain. The piezometric network has evolved a lot. . It currently consists of around ten piezometers, of which 2 piezometers are located in the public irrigated perimeter.

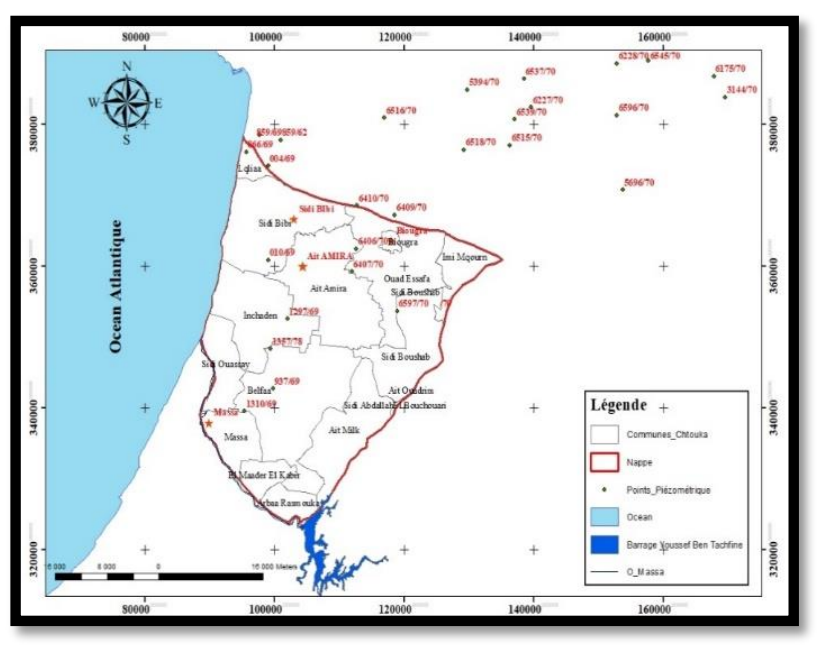

Figure 5: Piezometric Network Tracking Map

The piezometric level in the chtouka sheet has experienced a drop of around ten meters over several decades. This decrease on a reservoir of this size represents significant annual volumes.

The internal evolution of the piezometric varies differently from one sector to another.

\section{Evolution of the piezometric level:}
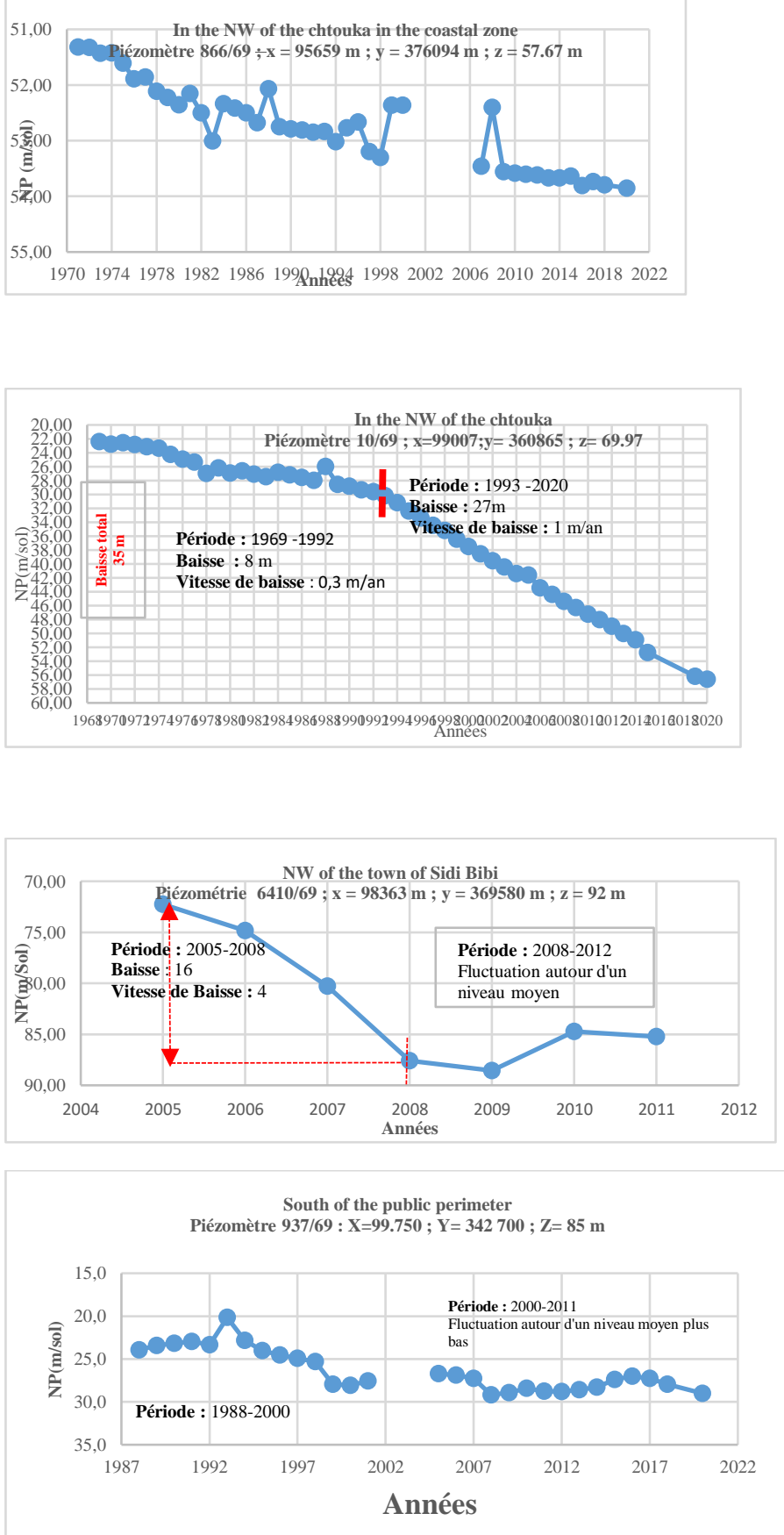

Figure 6: Piezometric history

Under the coastal zone, at the level of the piezometer at Mzar (866/69), the groundwater regime is still falling but with a low amplitude. It fell by $3 \mathrm{~m}$ between 1970 and 2015 but the water table has been stable since 2017 .

In the northern part, the water table has been declining since 1969. The drops are of the order of $35 \mathrm{~m}$ between 1969 and 2020 to the west of Ait Amira (Piezometer $10 / 69$ ), but the level piezometric has been stable there since 2016.

In the north-western part, at piezometer 6410/69 in the town of Sidi Bibi, the level of the water table fell by 16 
m between 2005 and 2008 (4 m / year) and fluctuated around an average level on the 2008-2011 period.

South of the public perimeter of Massa, the piezometric changes step by step. Indeed, the piezometer 937/69 indicates an average level of the water table over the period 1988-2000, followed by a lower average level over the period 2000-2020. The difference between the two levels is $5 \mathrm{~m}$.

Based on piezometric maps developed since the 1960s; the structure of the general flow is controlled by:

\& Feeding of the water table by the edge inputs

* A central drainage axis corresponding to the Oued Souss valley;

* A watershed that separates underground flows to the Souss Oued on the one hand, and the ocean on the other.

The general direction of groundwater flow is east to the west. In the Chtouka Plain, the direction of flow to the west. In the Chtouka Plain, the direction of flow is first South-East North-West, then it tends to curve towards the West as it approaches the Ocean

\subsection{Assessment of the Chtouka water table:}

\begin{tabular}{|c|c|c|c|}
\hline \multicolumn{2}{|c|}{ Entrées $\left(\mathrm{Mm}^{3} / \mathrm{an}\right)$} & \multicolumn{2}{|l|}{ Sorties $\left(\mathrm{Mm}^{3} / \mathrm{an}\right)$} \\
\hline $\begin{array}{l}\text { Direct } \\
\text { infiltration }\end{array}$ & 17,5 & \multirow[b]{2}{*}{ Pump-off (AEPI) } & \multirow[b]{2}{*}{7,2} \\
\hline $\begin{array}{l}\text { Contribution } \\
\text { of the N'sfa } \\
\text { wadi }\end{array}$ & 2 & & \\
\hline $\begin{array}{l}\text { Upward } \\
\text { drainage }\end{array}$ & 10 & Pump-off (irrigation) & 100 \\
\hline $\begin{array}{l}\text { Irrigation } \\
\text { water return }\end{array}$ & 28,4 & Flow to the ocean & 3 \\
\hline $\begin{array}{l}\text { Intakes by } \\
\text { Anti Atlas } \\
\text { abouchement }\end{array}$ & 1,7 & $\begin{array}{c}\text { Exits by drains and } \\
\text { sources (Oued Massa ) }\end{array}$ & 2,2 \\
\hline Total Entries & 59,6 & Total Outputs & 112,4 \\
\hline Bilan & \multicolumn{3}{|l|}{$-52,8$} \\
\hline
\end{tabular}

Tableau 2 : Assessment of the chtouka slick 2013[4]

\begin{tabular}{|c|c|c|c|}
\hline \multicolumn{2}{|c|}{ Entrées ( $\mathrm{Mm}^{3} / \mathrm{an}$ ) } & \multicolumn{2}{|c|}{ Sorties (Mm³/an) } \\
\hline $\begin{array}{l}\text { Direct } \\
\text { infiltration }\end{array}$ & 3.5 & \multirow[b]{2}{*}{ Pump-off (AEPI)) } & \multirow[b]{2}{*}{7.2} \\
\hline $\begin{array}{l}\text { Contribution of } \\
\text { the N'sfa wadi }\end{array}$ & 2 & & \\
\hline $\begin{array}{l}\text { Upward } \\
\text { drainage }\end{array}$ & 10 & Pump-off (irrigation) & 78 \\
\hline $\begin{array}{l}\text { Irrigation water } \\
\text { return }\end{array}$ & 15.7 & Flow to the ocean & 3 \\
\hline $\begin{array}{l}\text { Intakes by Anti } \\
\text { Atlas } \\
\text { abouchement }\end{array}$ & 1.7 & $\begin{array}{l}\text { Exits by drains and } \\
\text { sources (Oued } \\
\text { Massa) }\end{array}$ & 2.2 \\
\hline Total Entries & 33 & Total Outputs & 90.5 \\
\hline Bilan & -58 & & \\
\hline
\end{tabular}

Tableau 3 : Assessment of the chtouka slick 2015

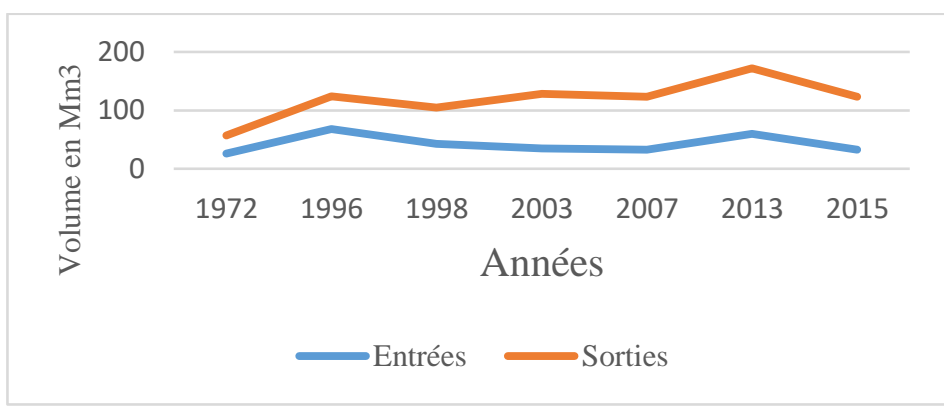

Figure 7 : Evolution of the assessment for Chtouka water table

The water balance of the water table depends, to a large extent, on the infiltration of local (on the plain) and distant (from the Anti-Atlas) precipitation, irrigation water from the Youssef Ben Tachfine dam, and upward drainage from deep water tables

The assessment of the chtouka slick for the year 2014-2015 shows a deficit of $58 \mathrm{Mm} 3$, while this deficit estimated under the PDAIRE for the year 19981999 was only $18 \mathrm{Mm} 3$. This increase in deficit can be explained by the increase in withdrawals due to the extension of the private perimeters of Chtouka Nord, the area of which increased from 2131 ha in 1998-1999 (PDAIRE) to 10,000 ha.

The aquifer withdrawals are evaluated at $85 \mathrm{Mm}^{3}$ and constitute the main outlet of the aquifer [5]

\section{Conclusion}

The open water table constitutes the main water resource of the multilayer system of the Chtouka plain. It is essentially contained in a heterogeneous Plio-quaternary filling, made up of dune sandstones, marly sands, lacustrine limestones, and poorly rolled gravel and pebbles. The hydrodynamic characteristics show variations to the heterogeneity of the reservoir.

The general direction of groundwater flow is east to west. In the Chtouka Plain, the direction of flow is first 
South-East North-West, then it tends to curve towards the West as it approaches the Ocean.

The temporal evolution of the piezometric makes it possible to highlight a generalized drawdown of the water table. This is generated by the combined effect of two main factors: the rainfall deficit and the overexploitation of the water table for agricultural and domestic needs.

The evolution of the hydrogeological balance of the water table depends largely on the infiltration of local (on the plain) and distant (from the Anti-Atlas) precipitation, irrigation water from the YBT dam, and the recycling of underground waters. The groundwater balance therefore shows the predominant part of withdrawals by pumping. This balance sheet shows an annual deficit of more than $50 \mathrm{Mm}^{3}$. With this deficit, the Chtouka water table is in a degraded quantitative state. This observed quantitative state is confirmed by an unfavorable interannual evolution of the piezometric.

\section{References}

[1] C. D. E. N. D. E. Chtouka, "( PROVINCE CHTOUKA AIT BAHA ) Mission 3 : Elaboration du plan $d$ ' action et du dossier du contrat de nappe Dossier technique: Synthèse," vol. Piéce $n^{\circ} 2$, 2015.

[2] "d Volume 3 - Ressources en souterraine_déf." .

[3] R. D. U. Maroc, A. Du, B. Hydraulique, and M. E. T. Draa, "ETUDE ET ELABORATION DE CONTRAT DE NAPPE DE CHTOUKA ( PROVINCE CHTOUKA AIT BAHA ) ETUDE ET ELABORATION DE CONTRAT DE NAPPE DE CHTOUKA ( PROVINCE CHTOUKA AIT BAHA )," 2016.

[4] P. Directeur et al., "Chapitre 1 : etat des lieux et evaluation des ressources en eau."

[5] C. D. E. N. D. E. Chtouka, “( PROVINCE CHTOUKA AIT BAHA ) Mission 3 : Elaboration du plan d ' action et du dossier du contrat de nappe," 2016. 